\title{
An appreciation of Orio Giarini: first Secretary General of the Geneva Association
}

\author{
Neil Doherty ${ }^{1}$
}

Accepted: 24 February 2021 / Published online: 29 March 2021

(c) The Geneva Association 2021

On being asked to write a short reflection on the works and impact of Orio Giarini, I feel rather like a man who has never seen an elephant and is then shown a picture of its trunk. The man is then asked to imagine what the whole beast must look like. Orio is a man of many accomplishments and each of us only sees a small part of him. My direct knowledge of him comes from my participation in the academic meetings of The Geneva Association, going way back to the mid-1970s. My comments will be drawn from this perspective. However, over the years, I have caught many wider glimpses of the man and these provide a context for understanding his contributions to insurance economics.

Orio was a big thinker who set research agendas-someone driven by social and economic policy issues, who thought beyond the boundaries into which we organise our activities and studies. From his long time association with the Club of Rome, he was keenly aware of the impact of risk in the face of limited resources. So when it came to insurance, he did not think of this as a self-contained sector of the economy, but as an integral part of a dynamic economic system. He undertook and championed studies in which insurance was seen as one pillar in a wider structure in which work, savings and social security would jointly address the risks that beset people over their lifetimes. He also recognised early on that the demand for corporate insurance must be understood through study of all a firm's risks (i.e. financial, marketing, business risk etc.) and the availability of non-insurance mechanisms for coping with them. In recognising this, he was way ahead of the curve in addressing corporate risk management.

With such ambitious insights, it is just as well that Orio was not so much a competitive scholar as a collaborator. From its early days, The Geneva Association was seeking research resources to address these expansive questions. As Orio himself describes in his 'history' of the Association, he commissioned reports from professional research organisations such as his old employer Battelle, Stanford Consulting

Neil Doherty

doherty@wharton.upenn.edu

1 Fredrick H. Ecker Professor Emeritus of Insurance and Risk Management, The Wharton School, Philadelphia, USA 
and Arthur D. Little. From these arose a series of publications and seminars which have expanded and continue to this day. This type of professional research must have provided interesting fodder for the CEOs at the Association's meetings, but Orio's nimble mind was reaching further afield. From the start, The Geneva Association was to be a research hub and, while he was consumed with pressing real world issues facing society and the insurance industry, he clearly saw an integral role for academic research.

Here, I would like to pause to say a few words about insurance as an academic subject in the early 1970s when the Association was founded. At that time, there were a number of professors of insurance to be found in the world's universities, mostly in the U.S., a few in Europe, and a smattering elsewhere. These included actuaries and others who usually considered themselves to be economists. However (and here I must be careful) it would be difficult to say that a well-defined subject called 'insurance economics' really existed. Certainly, insurance was taught, but largely as a description of the marketplace, its institutions and its contracts-a practical training for those seeking a career. Valuable research was also undoubtedly being undertaken - examples include the impact of anti-competitive practices and degree of competition in insurance, economies of scale, efficiency of operations, etc. However, we rarely found research producing new economic concepts in this early work and insurance professors tended to write for specialised outlets, rather than for mainstream economics or finance journals.

Nevertheless, original research that would fundamentally change the way we think about insurance and risk management was appearing. However, it was mainline economists that were at this frontier. For example, Kenneth Arrow had recently produced his path breaking paper that analysed insurance demand and showed that full insurance was not optimal. Pauly had just written a response to Arrow's paper, introducing the economics of moral hazard, and others like Holmstrom had developed this into the principle agent model. Black and Scholes had just published their option pricing model. Rothschild and Stiglitz were just about to write their famous adverse selection paper. Earlier, Modigliani and Miller had written their paper rethinking capital structure and Lintner, Mossin and Miller had separately produced the capital asset pricing model (CAPM). All of these insights would fundamentally change how we thought about risk management. ${ }^{1}$

Someone like Orio Giarini might have seen these radical developments in economic thought as peripheral. After all, he was trying to persuade the CEOs of his contributing insurance companies that the Association's research activities could lead to value-adding business decisions and strategies. Not so. Orio embraced new academic ideas and quickly opened a forum to air such radical concepts. And so, The Geneva Association quickly began its academic meetings.

The Geneva Academic Group met for the first time in 1974. I was a fresh research fellow at the University of Nottingham at the time. My colleague, Bob Carter, was

\footnotetext{
1 One notable exception to the general rule: the CAPM was foreshadowed by the actuary Karl Borch, who showed that the capital market price equilibrium was simply a generalisation of his reinsurance market equilibrium.
} 
invited to that first meeting together with a small group including Dieter Farny, Elmar Helten, Matthias Haller and Gerry Dickinson. I was a little jealous not to be included, but I was invited to a meeting in the next year. At that time, Bob Carter and I were editing a volume on risk management, and Orio had set up a meeting on that topic. It is a long time ago, but I do have this enduring memory of my first encounter with Orio, who introduced the meeting with a sweeping survey of the topic. In our book, Bob and I had been expansive in that we had tried to look at all possible corporate strategies for addressing risk, but Orio was going far beyond this by including social and regulatory policies as well. Having set the stage, Orio, as was often his way, let the discussion proceed with little intervention until he finally delivered a comprehensive summary at the end.

The first group of university-based insurance economists attending the Geneva meetings were specialists in insurance, and tended to have close relationships with the industry. Some were on boards or did consulting, and many were known to the CEO members of the Association. It is therefore natural that they would be brought into a partnership with industry leaders and that their research would be considered relevant. Orio's genius was that he saw beyond this group to the more diverse community of academics whose research might have more profound implications for insurance and risk management strategy. He signalled this outreach from the start with the establishment of the Geneva Lecture series and invited the recent Nobel Laureate, Kenneth Arrow to be the first speaker. This lecture series has continued to this day and includes other Nobel prize winners in its alumni.

Soon, the Geneva Academic Meetings would rival their North American counterpart, the Risk Theory Seminar, as a high-powered research forum. They have provided a venue for new generations of scholars who have brought innovative ideas to risk management research. Scholars such as Henri Loubergé, Harris Schlesinger, Georges Dionne, Louis Eeckhoudt, Keith Crocker, Peter Zweifel, Christian Gollier and many others who have been inspirations to me, have been regulars. Orio was a constant presence. He rarely immersed himself in the technical minutiae of the discussions, but always encouraged new ideas, made connections with seemingly unrelated avenues of practice and research, and often planted the germs of new thinking for scholars to latch onto. In this way, Orio championed this thriving academic subject we call 'insurance economics' or more generally 'risk management'.

But I see Orio's legacy in much broader terms. These meetings were so much more than isolated events in the annual calendars of professors seeking to share their arcane theories amongst their peers. They were - are-an integral part of a network in which practitioners (from both public and private sectors) and researchers (both professional and academic) explore and make available innovative ideas solving problems of risk management and generating new opportunities.

To see the impact of Orio's vision, let me step back with some personal reflections. I started my career in the insurance industry in England at the bottom rung of a long ladder. Had I stayed, I would have climbed rung by rung to some height that reflected the limits of my ability. The industry was one of promotion-fromwithin-believing that one could only truly understand it from years of experience. The industry tended to be insular and resistant to ideas from outside. Rarely would insurers recruit people from other industries who might have specialised skills in 
marketing, finance, strategy or organisational design. And academics might be useful in educating people as long as they tamely reflected the subtle practice of insurance as it had evolved over the decades.

Contrast that with today and we see a more vibrant and open industry. Insurers have adapted their products and strategies to a broader and changing risk landscape. There is an interchange of people and ideas with other economic sectors and a robust dialogue with those engaged in research. Orio has contributed to this exchange with his own extensive and influential professional research. Even more importantly, he has been the nexus. With generosity and grace, he has sought out and encouraged academics towards new avenues of risk management research. And, for practitioners, he has been the conduit to those new ways of thinking.

Let me close with another personal observation. As a fun retirement project, I have been reading and writing about Leonardo da Vinci. Here is someone who is almost impossible to classify - his genius was that he did not recognise conventional boundaries. His art was informed by his investigations in science, engineering and mathematics and vice versa. And even as a scientist and engineer, he reached across conventional fields, recognising the wholeness of nature, drawing from one discipline to make advancements in another. In this way, he was able to accomplish so much across so many different fronts (hydraulics, optics, anatomy, aviation etc., as well as in art).

And so it was with Orio-he was a big and expansive thinker who refused to recognise hard boundaries! To understand insurance and how it might contribute to social welfare, he looked past the distinctions between theory and practice. He showed us that risk management is an activity that calls upon all sectors of the economy and must be practiced at all stages of life; and that progress depends just as much on the flow of information, ideas and people across institutions and disciplines, as it does on 'experts' within each field. Four or five decades ago, when The Geneva Association first started, this was radical thinking but it is now widely accepted. This was Orio's genius, he was 'in the van' and The Geneva Association is the embodiment of this vision.

Publisher's Note Springer Nature remains neutral with regard to jurisdictional claims in published maps and institutional affiliations.

\section{About the author}

Neil Doherty is Professor Emeritus at the Wharton School of the University of Pennsylvania. After an academic career specialising in risk management, he is currently working on two poetry volumes: one on the logic of paradox and another on the life and works of Leonardo da Vinci. 